\title{
QUEEN'S
UNIVERSITY
BELFAST
}

\section{Branding strategies for high technology products: The effects of consumer and product innovativeness}

Truong, Y., Klink, R. R., Simmons, G., Grinstein , A., \& Palmer, M. (2017). Branding strategies for high technology products: The effects of consumer and product innovativeness. Journal of Business Research, 70, 85-91. https://doi.org/10.1016/j.jbusres.2016.07.003

Published in:

Journal of Business Research

Document Version:

Peer reviewed version

Queen's University Belfast - Research Portal:

Link to publication record in Queen's University Belfast Research Portal

Publisher rights

Copyright 2016 Elsevier

This manuscript is distributed under a Creative Commons Attribution-NonCommercial-NoDerivs License

(https://creativecommons.org/licenses/by-nc-nd/4.0/), which permits distribution and reproduction for non-commercial purposes, provided the author and source are cited.

\section{General rights}

Copyright for the publications made accessible via the Queen's University Belfast Research Portal is retained by the author(s) and / or other copyright owners and it is a condition of accessing these publications that users recognise and abide by the legal requirements associated with these rights.

Take down policy

The Research Portal is Queen's institutional repository that provides access to Queen's research output. Every effort has been made to ensure that content in the Research Portal does not infringe any person's rights, or applicable UK laws. If you discover content in the Research Portal that you believe breaches copyright or violates any law, please contact openaccess@qub.ac.uk. 


\title{
BRANDING STRATEGIES FOR HIGH TECHNOLOGY PRODUCTS: THE EFFECTS OF CONSUMER AND PRODUCT INNOVATIVENESS
}

\begin{abstract}
Selecting the appropriate brand name is a critical factor in determining new product success. To date, little research exists to inform whether the new product should carry a new brand name or borrow an existing one from another product (or set of products). Prior research has found consumer response to the alternate branding strategies depends on consumer innovativeness - i.e., one's propensity to adopt new products earlier vs. later. Specifically, unlike later adopters, earlier adopters were found to favor new brands on FMCG products. We posit that these findings may not generalize to High-Technology (HT) products. One of the hallmark characteristics that differentiate products in HT categories from other product categories, including FMCG, is uncertainty. By drawing on theory from Dowling and Staelin's (1994) framework on perceived-risk handling, we propose that both earlier and later adopters will use known brands to cope with the elevated risk associated with an innovative HT product. Two studies are reported. In an experimental setting, Study 1 found that, contrary to prior research, the effect of consumer innovativeness on new product evaluation is not greater for new (vs. existing) brand names on more innovative HT products.

Furthermore, we found that highly innovative consumers evaluated innovative HT products more favorably if they carried an existing (vs. new) brand name. In a field setting, Study 2 used netnography to corroborate these findings. A managerial contribution of our research is to help the practitioner choose an effective branding strategy for HT innovations. A theoretical contribution of our work is to include key elements of Dowling and Staelin's framework (i.e. category-specific risk, product-specific risk and consumers' acceptable level of risk) in advancing both branding and diffusion theory. Perhaps more importantly, our work brings needed attention to a critical, yet under-researched area - i.e., branding and HT products.
\end{abstract}

Keywords: Innovation, branding, consumer innovativeness, product innovativeness, hightechnology products. 


\section{INTRODUCTION}

The brand name is an important driver of new product success (Cooper 1994). When naming a new product, companies often choose to either create a new brand name or borrow an existing one from another product - i.e., develop a brand or line extension (e.g., Apple TV or Heineken Light beer). Some of the advantages of using an existing brand name are that it involves lower marketing and brand development costs for the new product (Smith and Park, 1992). However, if consumers perceive inconsistency between the existing name and new product, consumers may react unfavorably toward the new product, as well as the brand and its existing products (Aaker and Keller, 1990; Loken and John, 1993).

Despite the risks, extending a brand name to new products has been a widely popular growth strategy for companies over the past few decades (Dall'Olmo et al., 2013; Ambler and Styles, 1997). In a study by Research International, over $80 \%$ of new product launches involve use of an existing name (Les Echos, 2004). Others have indicated that that the choice of an existing name for a new product is as high as 95\% (Ogiba, 1988; Somji, 2000).

Perhaps driving the popularity of extending brand names is the belief that consumers respond more favorably to established brands, as brand familiarity helps reduce uncertainty in new product purchases (Klink and Athaide, 2010; Smith and Park, 1992). Klink and Athaide (2010), however, found that this preference is not uniform across consumers. Rather, one's preference for existing brand names is influenced by consumer innovativeness - i.e., one's propensity to adopt earlier vs. later (Rogers, 2003). Specifically, while the mass market may prefer existing brands, highly innovative consumers were found to evaluate products carrying 
new brands more favorably than brand extensions. This finding may be explained by earlier adopters' greater tolerance, or perhaps even preference, for risk (Rogers, 2003).

Importantly, Klink and Athaide (2010) conducted their study with fast moving consumer goods (FCMG) - e.g., mouthwash, chewing gum, candy bar, etc. For consumers, new FMCG products typically carry relatively little perceived risk - i.e., (a) the risk related to purchasing a specific product in a given category and (b) the risk inherent to purchasing any product in the category (Dowling and Staelin, 1994). Regarding product-specific risk, new FMCG products usually involve less innovation, often modifying an existing product feature such as fewer calories, newer flavor, more recyclable packaging, etc. More innovative products often introduce new features that likely carry more uncertainty for consumers. With respect to category-specific risk, new FMCG products are often introduced in mature product categories. Relative to earlier stages of the life cycle, mature product categories could be expected to involve less risk for consumers, as the level of familiarity, knowledge, and experience that a consumer has with a product category likely increases over time.

While innovations in FMCG categories typically carry lower perceived risk, the same cannot be said of innovations in high-technology $(\mathrm{HT})$ categories. Indeed, a hallmark characteristic of HT industries is uncertainty (Moriarity and Kosnik, 1989). Uncertainty characterizes both the HT innovation (e.g., will the new product function as promised?) and the HT market (e.g., how quickly will market needs change?). With respect to the innovation, the greater uncertainty could arise from new product features - particularly for more innovative products. For example, both bloggers and consumers were initially skeptical about the curved screen of the new Galaxy S6 Edge when it was presented in 2015 at the World Mobile Congress, mainly because they were unsure about the technical reliability of the 
curved technology and the long-term touch-experience. This initial skepticism is inherent to this kind of innovative features because new technologies tend to suffer from a liability of newness, that is, they do not have a history of past performance. As a consequence, there is greater uncertainty about the potential flaws involved in such an immature technology, which are often corrected only in the following versions.

Furthermore, highly innovative products may create new categories where consumer familiarity, knowledge and experience is limited - thus elevating perceived risk. It stands to reason that the level of perceived risk that accompanies more innovative products could reach a point where even earlier adopters are adversely affected. That is, the perceived risk of a new product purchase may exceed the individual's acceptable level of risk (Dowling and Staelin, 1994). In such situations, both earlier and later adopters may seek out existing brands to help cope with the innovation's uncertainty.

The purpose of this research is to understand how consumers respond to alternate branding strategies for HT products. In particular, we seek to examine whether earlier adopters - i.e., individuals with high levels of consumer innovativeness - will continue to favor new brands for HT products. We expect that, for more innovative HT products, earlier adopters will reverse their preferences and favor existing brands. It is important to note that accurately gauging the response of earlier adopters is critical because they often represent the main target market for a new product introduction (Mahajan and Muller, 1998). Even when they are not the primary target, understanding their response is critical because they influence later adopters. By accurately gauging the response of earlier adopters, we help inform brand naming decisions for HT innovations. 
In terms of theoretical contribution, we extend theory developed and tested on FMCG products to HT products. We add to extant theory on alternate branding strategies to include Dowling and Staelin's (1994) constructs of product category-specific risk, product-specific risk and consumers' level of acceptable risk. In doing so, we help reconcile theories on consumer innovativeness and branding which can offer opposing prescriptions. On the one hand, the literature on consumer innovativeness suggests using new brand names on new products to appeal to innovators' "desire for the rash, daring, and the risky" (Rogers, 2003, pg. 282), as prescribed by Klink and Athaide (2010). On the other hand, branding theory advocates using established brand names to reduce the perceived risk of a new product purchase. Because (a) branding is believed to be more important for HT products than for packaged goods (Mohr, Sengupta, and Slater, 2010) and (b) the rate of technological innovation introduced in the marketplace is expected to accelerate, advancing theory at the intersection of branding and HT products is of significant importance.

In terms of organization of this paper, the next section discusses the theoretical background, which is rooted in Dowling and Staelin's (1994) framework for risk-handling, and proposes hypotheses. This is followed by a description of the research methods employed which include an experimental study and a field study. Following the presentation of results, we discuss managerial implications, acknowledge limitations and provide direction for future research.

\section{THEORETICAL BACKGROUND}

The Dowling and Staelin (1994) framework considers perceived risk in a new product purchase to comprise both product-specific risk and category-specific risk. Consumers deal with unacceptable levels of risk by engaging in risk-reducing strategies - e.g., seeking a known 
brand. The need to engage in such strategies is a function of one's level of acceptable risk, or risk tolerance. As we will discuss, individuals with higher levels of consumer innovativeness have higher thresholds for perceived risk and thus are less likely to engage in risk-reduction strategies - i.e., rely less on known brands and perhaps exhibit relatively more favorable responses toward new brands. The Dowling and Staelin model is compatible with the conflict theory model of decision making (Janis and Mann, 1977), the information-processing paradigm of consumer choice (Bettman, 1979), and economically-based search models (Stigler, 1961).

\section{Consumer Perceived Risk and Risk-Reduction Strategies}

Perceived risk can be defined as consumer perception of the uncertainty and adverse consequences of transactions (Bauer, 1960). This risk is common to new product purchase and can include financial risk, performance risk, psychological risk, time risk, physical risk and social risk (Jacoby and Kaplan, 1972; Brooker, 1984). As mentioned, perceived risk is comprised of both category-specific risk and product-specific risk, which is analogous to Bettman's (1973) "inherent risk" and "handled risk." Category-specific risk is the perceived risk in purchasing any product in a given product category. For instance, a purchase in the mountain bike category is likely to carry more risk than a purchase in the bottled water category. Product-specific risk is associated with the particular product being considered in the product category. To illustrate, purchasing a mountain bike without a warranty is likely to carry more risk than purchasing a mountain bike with a warranty.

To help cope with perceived risk, consumers will engage in risk reduction strategies. Roselius (1971) identifies eleven methods of risk reduction. Namely, consumers will reduce risk by relying on: endorsements, brand loyalty, brand image/familiarity, private testing, 
store image, free samples, money-back guarantees, government testing, additional shopping, buying the most expensive product, and word of mouth.

Roselius (1971) found that a well-known brand is one of the most favored risk reduction strategies employed by consumers. A well-known brand provides an implied promise that outcomes resulting from a new product purchase will be consistent with what consumers have historically associated with the brand (Erdem and Swait, 1998; Wernerfelt, 1988). With respect to brand extensions, consumers can draw on their experiences and knowledge about other products affiliated with the brand to make inferences about what their experiences may be like with the new product.

Even if the consumer does not have extensive experience with the brand, an existing brand can still reduce perceived risk. By extending an established name to a new product, the brand acts as "collateral" for the quality of the new product (Wernerfelt, 1988). Given a high quality brand, consumers may reason that a company will not risk their prior investment in the brand by placing it on a product of lower quality (Smith and Park, 1992; DelVecchio and Smith, 2005). Accordingly, a new product with a new brand name will likely carry more uncertainty and risk than a brand extension, assuming there is a fit between the brand and new product. As we will discuss, the extent to which a consumer will need to rely on a familiar brand as a risk reduction strategy depends on their consumer innovativeness.

\section{Level of Acceptable Risk and Consumer Innovativeness}

Consumer innovativeness has been considered a generalized personality trait in individuals (Midgley and Dowling, 1993; Rogers, 2003). However, Hirunyawipada and Paswan (2006) contend that the predictability of the global innovativeness trait is elevated by incorporating domain-specific innovativeness - i.e., an individual's predisposition toward 
a product category, and their tendency to acquire product innovations or related information within a specific domain (Goldsmith and Hofacker, 1991). This tendency is determined by the interaction between a more innate level of consumer innovativeness and a focused interest in a product category (Roerich, Valette-Florence and Ferrandi, 2002; Roehrich, 2004; Midgley and Dowling, 1978).

One of the primary characteristics that determine whether an individual adopts early or not is their level of risk tolerance. Indeed, the salient trait that distinguishes consumer innovators - i.e., those adopters with the highest levels of innovativeness - from later adopters is their venturesomeness, a comfort with taking risk (Rogers, 2003). According to Dowling and Staelin, the need to engage in a risk reduction strategy is a function of one's acceptable level of risk. Thus, because of their lower level of acceptable risk, one might expect that individuals with lower levels of consumer innovativeness will need to cope with perceived risk by favoring known brands on new products. On the other hand, consumers with higher levels of innovativeness are less likely to engage in risk reduction strategies. Instead, their venturesomeness or risk-seeking propensity may lead them to favor new brands. As mentioned, Klink and Athaide (2010) found that while later adopters favor known brands, earlier adopters favor new brands on FMCG products. In short, because of their greater tolerance for risk, earlier adopters may not need to rely on known brands with new product purchases.

\section{Product-Category Risk and HT Products}

While FMCG's are generally considered low involvement purchases for consumers (Helmig, Huber and Leeflang, 2010), this may not be so with HT innovations. With FMCG purchases, consumers typically do not search extensively for information about brands, 
evaluate their characteristics, or make time consuming decisions on which brand to buy (Kotler and Armstrong, 2016). The lack of uncertainty usually entails less alternative evaluation and thus an inability to identify key differences between leading FMCG brands (McWilliam, 1997; Silayoi and Speece, 2004). However, HT products may involve features that are complex and prone to rapid change with a shorter product life-cycle (Temporal and Lee, 2000; Winkler, 1999; Zajas and Crowley, 1995). Consumers may require greater technical savvy in evaluation (Tripat and Lei, 2009). The inherent uncertainty can lead to negative emotions of anxiety and fear and lead to avoidance of the innovation (Castano et al., 2008; Mick and Fournier, 1998). In short, category-specific risk will typically be greater for HT products than FMCG products.

\section{Product-Specific Risk and Product Innovativeness}

It is important to recognize that product-specific risk varies across HT products. For example, an iPhone 5 owner would likely encounter less functional, symbolic and financial risk in purchasing a new iPhone 6 relative to purchasing a new wearable technology product, such as Google Glass. Accordingly, in our examination of alternate branding strategies for HT products, we account for different levels of product innovativeness (Chandy, Prabhu and Antia, 2003; Wu, Balasubramanian and Mahajan, 2004). Less innovative products require less change in use behavior by consumers (Chandy and Tellis, 2000; Gourville, 2006). Such innovations can be considered "incremental," as they are adaptations or on-going improvements to products or technologies within a working paradigm (Fang, 2008; Han, Ki and Srivastava, 1998). On the other hand, more innovative products can be "radical" in nature - i.e., discontinuous, generational or breakthrough and often contain a substantially 
new technology (Govindarajan and Kopalle, 2006). In short, greater levels of product innovativeness result in more uncertainty for consumers (Hoeffler, 2003).

Klink and Athaide (2010) found that the effect of consumer innovativeness on new product evaluation of FMCG goods is greater for new, relative to existing, brand names. In essence, as consumer innovativeness increases the need to rely on a known brand decreases. Furthermore, Klink and Athaide (2010) found that for earlier adopters, new brands not only become a more viable option, but the preferred option for naming FMCG products. Extending the aforementioned theory and findings from FMCG, we expect the following for HT products:

H1: The effect of consumer innovativeness on new product evaluation is greater for HT products carrying new (vs. existing) brand names.

As discussed, innovative HT products carry more perceived risk than FMCG products. Accordingly, innovative HT products are more likely to surpass the acceptable level of perceived risk, even for earlier adopters. In short, new brands will no longer become relatively more appealing for innovative HT products, even as consumer innovativeness increases. Stated formally:

$\mathrm{H}$ 2: For more innovative HT products, the effect of consumer innovativeness on new product evaluation is not greater for new (vs. existing) brand names.

Furthermore, we expect highly innovative individuals will engage in risk reduction strategies with innovative HT products, by favoring known brands. Stated more formally:

H3: Highly innovative individuals will evaluate more innovative HT products more favorably with existing (vs. new) brands. 


\section{METHODOLOGY}

\section{Study 1 - Experimental Study}

Study 1 involved a controlled on-line experiment involving HT innovations carrying either an established brand name or a new brand name. For the HT innovations, we selected new smartphones that were less innovative (termed "incremental") and more innovative (termed "radical") in nature.

Procedure. From an international panel of over 60,000 consumers, a quota random sampling process selected 520 participants residing in the U.K. Selected participants were over 25 years of age and had a gender split of $70 \%$ male vs. $30 \%$ female. We designed a 2 (new/established brand name) $\times 2$ (incremental/radical innovation) between-subjects online experiment. Participants were randomly assigned to one of the four conditions. Participants were shown a one-page description of a new smartphone, which varied in terms of product innovativeness. The characteristics were defined with the help of a group of 11 marketing managers working for a large mobile technology company. The experts recommended Samsung for the established brand name and Beepo for the fictitious new brand name. The incremental innovation consisted of slight to moderate improvements in CPU, screen resolution, disk space, battery life, and media capabilities on one of the highest performing mobile smartphones. The radical innovation consisted of new technologies that were substantially improved over existing ones, including an ultrathin 3-D screen, quad-core CPU, x4 disk space, $x 3$ battery life, and advanced gaming and software capabilities. The radical innovation used non-existent technologies that experts considered disruptive. We used the same illustration for all four conditions to avoid bias due to product design (Appendix 1). 
Measures. Consumer innovativeness was measured with four scales borrowed from Goldsmith and Hofacker (1991) and Goldsmith et al. (1998). The domain of interest was mobile phones and accordingly subjects were primed with their experience with these products. Using seven-point disagree/agree scales, the items were: “Overall, I'm interested in the latest technology in mobile phones"; "I often visit the mobile phone department of a store"; "I like to purchase mobile phones before others do"; "If I needed to buy a mobile phone, I would buy the latest one available." The Cronbach alpha for consumer innovativeness was .87 .

New product evaluation was measured by assessing overall attitude toward the product (Ajzen and Fishbein 1980). The measure consisted of four items using 7-point disagree/agree anchors: "Overall, this product is interesting"; "I would like to try this product"; "I would probably take a look at this product in a store"; "Overall, I like this product." The Cronbach alpha for new product evaluation was .92.

To validate the smartphone descriptions varied in product innovativeness, a separate sample of 100 individuals rated product innovativeness on a seven-point Likert scale ranging from "not innovative" to "extremely innovative." The mean scores for the incremental versus the radical innovations were significantly different $\left(M_{\text {incremental }}=1.95 \mathrm{vs} . \mathrm{M}_{\text {radical }}=6.42, p<.01\right)$. The same item was included in the questionnaire as a manipulation check.

Manipulation checks. As desired, the established brand name was more familiar to participants than the new brand name ( $M_{\text {new }}=1.69$ vs. $\left.M_{\text {est }}=6.70, p<.01\right)$. In terms of product innovativeness, the radical innovation was perceived to be more innovative than the incremental innovation ( $\mathrm{M}_{\text {incremental }}=1.92$ vs. $\left.\mathrm{M}_{\text {radical }}=6.31, p<.01\right)$. Additionally, we included a two-item measure of perceived technical risk "I may need some help when first using this 
product", and "I'm not sure I can make this product work" as a second check for the difference between the radical and incremental smartphones. The manipulation check for perceived technical risk revealed that the radical version was perceived to be significantly riskier than the incremental version $\left(\mathrm{M}_{\text {incremental(est } / \text { new })}=4.46-4.50-\mathrm{vs} . \mathrm{M}_{\text {radical }(\text { est } / \text { new })}=4.70\right.$ $4.75, p<.05)$.

Results. ANOVA confirmed that the four conditions did not differ statistically in consumer innovativeness $\left(M_{\text {inc,estab }}=4.24\right.$ vs. $M_{\text {inc,new }}=4.23$ vs. $M_{\text {rad,estab }}=4.46$ vs. $M_{\text {rad, new }}=$ 4.26, $F=.63, p>.10)$. We mean-centered consumer innovativeness (Aiken and West, 1991) and performed a series of multiple regression analyses as reported in Table 1. Brand name was coded such that $-1=$ new brand/+1=established brand. Innovation type was coded such that $-1=$ incremental and $+1=$ radical.

Insert Table 1 about here

Model 1 regressed new product evaluation on consumer innovativeness. As expected, the simple effect of consumer innovativeness is significant $(\beta=.533, p<.001)$. To test $\mathrm{H} 2$, Model 2 regressed new product evaluation on consumer innovativeness, brand name, and consumer innovativeness $\mathrm{X}$ brand name. As expected, the interaction of consumer innovativeness and brand name is significant and in the predicted direction $(\beta=-$ $.053, p<.05)$. Specifically, the positive effect of using an existing brand on new product evaluations for HT products decreases as consumer innovativeness increases. Thus $\mathrm{H} 1$ is supported. 
To test $\mathrm{H} 2$, Model 3 reran Model 2 but included only radical smartphones. As expected, the interaction term of consumer innovativeness and brand name is not significant $(\beta=.015, p>.10)$, indicating that the effect of consumer innovativeness on new product evaluation is not greater for new brand names on more innovative HT products. To provide greater insight, Model 4 included all of the simple effects and interaction terms. The three-way interaction of consumer innovativeness, brand name and innovation type is significantly positive $(\beta=.072, p<.01)$. Given the coding scheme, this result indicates that the positive effect of using an existing brand on a more innovative HT product increases as consumer innovativeness increases. $\mathrm{H} 2$ is supported.

Figures $1 \mathrm{a}$ and $1 \mathrm{~b}$ graphically represent the interaction term for the incremental and radical innovations, respectively. To gain further insight into the interaction term, we performed a spotlight analysis (Spiller et al., 2013); specifically, we ran regressions for (a) incremental smartphone only and (b) radical smartphone only, at the level of one standard deviation above the mean of consumer innovativeness. For the incremental smartphone, we found that the existing brand name had a significant negative effect on product evaluation for highly innovative individuals $(\beta=-.382, z=-2.24, p<.05)$. This significant difference indicates that highly innovative individuals evaluated the incremental smartphone more favorably with a new (vs. existing) brand name. This finding is consistent with Klink and Athaide (2010) which found that highly innovative individuals favor new brands on new products.

Insert Figures $1 a$ and $1 b$ about here 
For the radical smartphone, we found that the established brand name had a significant positive effect on product evaluation for highly innovative individuals $(\beta=.311$, $z=1.75, p<.05)$. This significant difference indicates that earlier adopters evaluated the radical smartphone more favorably if it carried an existing (vs. a new) brand name. This finding runs counter to prior work which found highly innovative consumers preferring new brands on FMCG products. H3 is supported.

To provide further insight, we examined the new product evaluation scores for those individuals who were above 1 standard deviation on consumer innovativeness. This top $16 \%$ approximates the combination of Rogers (2003) innovators and early adopters categories. This combination of categories represents a critical subset of adopters for HT products (Moore, 2004). As expected, this group of highly innovative individuals evaluated the radical smartphone more favorably if it carried an established (vs. new) brand name $\left(\mathrm{M}_{\text {new }}=5.92\right.$, Mestablished=6.85, $\mathrm{p}<.01)$, further supporting $\mathrm{H} 3$.

\section{Study 2 - Field Study}

To shed light on the external validity of our Study 1 findings, Study 2 uses online field data to examine actual consumer responses to alternate branding strategies for HT innovations in the marketplace. 
Procedure. Data was collected about two HT product categories (notebook computers and mobile phones) from two prominent HT product online discussion forums (cnet.com and tomshardware.com) in the year 2010. For notebooks, we selected the latest models from an established brand (Sony Vaio FW) and a less-established brand (MSI Xseries). Both models involved incremental improvements - i.e., higher processing power, more storage and memory, and newer design. While Sony is a well-known, global brand, MSI is a lesser-known, Taiwan-based component manufacturer which began manufacturing notebooks approximately six years ago and only recently entered the U.S. market.

For mobile phones, we selected the latest smartphone model from an established brand (Samsung Galaxy S2) and a lesser-known brand (HTC One). Both smartphones were perceived by prominent forums and bloggers to bring relatively novel or radical changes i.e., revolutionary user interface, substantial increase in processing power, introduction of a large market for applications, and a considerably larger touch screen. While Samsung smartphones have been well known globally for more than 10 years, HTC is a Taiwan-based company that is less familiar, having launched its first successful high-end smartphone more recently (2009). We pre-tested the two brands on a representative sample of 100 consumers in the UK to ensure that Sony and Samsung were perceived as well-established brands while MSI ( $\mathrm{M}_{\text {sony }}=6.52$ vs. $\left.\mathrm{M}_{\mathrm{Msi}}=1.89, p<.01\right)$ and $H T C\left(\mathrm{M}_{\text {samsung }}=6.65\right.$ vs. $\left.\mathrm{M}_{\mathrm{Htc}}=2.76, p<.01\right)$ were viewed as less-established brands.

Earlier adopters (those with high levels of consumer innovativeness) tend to have more social participation and offer more opinion leadership than later adopters (Rogers 2003; Gatignon and Robertson 1985). Our measure of consumer innovativeness borrows closely from Goldsmith and Hofacker (1991), which reports a correlation of .80 between 
their measure of innovativeness and a seven-item measure of opinion leadership.

Accordingly, the number of posts made to the entire discussion forums served as a proxy for consumer innovativeness. We point out that such a proxy is also consistent with widelyaccepted conceptualizations of diffusion and consumer innovativeness founded on interpersonal communication processes (e.g., Rogers and Shoemaker, 1971; Midgley and Dowling, 1978). Given the large number of posts on the forum, we decided that those having over 800 posts were labeled as "more innovative individuals," while those having less than 100 posts were labeled as "less innovative individuals." We restricted our analysis to posts in the product review sections because such posts better represent opinion leadership than posts made to other areas of the forums - e.g., sections devoted to technical assistance.

Analysis. 2,600 posts supplied by 393 individuals were downloaded from the two online discussion forums; the total number of posts made by each group was approximately equal. Given the classification scheme described above, we had two subgroups: 69 highinnovative vs. 118 low-innovative individuals). We used a sentiment analysis software called "SPSS Text Analytics" to detect the impressions of participants by extracting terms and qualifiers, which were further automatically categorized into positive and negative. SPSS Text Analytics uses Natural Language Processing technologies to perform statistical analysis on textual contents. The software enabled us to identify how favorably an audience perceives an item (for example a brand or product), by capturing and classifying the terms and qualifiers contained in free texts into positive and negative based on sophisticated dictionaries. After the automatic classification, we configured the software to adapt the codification process to the context of the study by classifying neutral or unknown terms into positive or negative terms. For example, the word "cool" was classified as a positive term. 
Results. We analyzed the forum comments regarding the target HT product innovations from both more innovative and less innovative individuals. For the less innovative products (notebooks), the results revealed that more innovative individuals were more favorable toward $M S I$ than Sony ( $71 \%$ vs. $41 \%$ positive terms; $z=5.700, p<.01$, twotailed), whereas less innovative individuals responded more favorably toward Sony than MSI ( $62 \%$ vs. $50 \%$ positive terms; $z=2.072, p<.05$, two-tailed). On the other hand, for the more innovative product (smartphone), the results indicate that Samsung elicited more favorable terms than HTC for more innovative individuals ( $75 \%$ vs. $50 \%$ positive terms, $p<.01$ ), as well as less innovative individuals ( $65 \%$ vs. $55 \%$ positive terms, $p<.05$ ). Using our classification of individuals (i.e., 69 high-innovative vs. 118 low-innovative individuals), we used the clustering tool of the software to group the categories of terms among the two groups in both product categories. The results suggest that the focus of more innovative individuals was on technical characteristics of the HT product, whereas the focus of less innovative individuals was on the cost/benefit ratio. Examples of terms of in the "technical characteristics" cluster are: Screen size, battery life, processing power, case materials, screen brand, model version, and chipset. Examples of terms in the "cost/benefit" cluster are: Price, cheap, convenient, user-friendly, cost, beautiful, and easy.

Discussion. The results of Study 2 provide some initial support from the marketplace that individuals with relatively lower levels of innovativeness respond more favorably toward established brands than relatively newer brands. Highly innovative individuals responded more favorably to the newer brand but only for the incremental innovation. For the more radical innovation, highly innovative individuals responded more positively toward established brands than newer brands. In short, these results corroborate the findings of Study 1. 


\section{DISCUSSION}

Selecting the appropriate brand name is a critical factor to new product success. To date, little research exists to inform whether the new product should carry a new brand name or borrow an existing one from another product (or set of products). Klink and Athaide (2010) found consumer response to the alternate branding strategies depends on the individual's level of consumer innovativeness. Specifically, unlike later adopters, earlier adopters were found to favor new brands on new FMCG products.

We offer that these findings may not generalize to HT products. Indeed, a widely held belief is that marketing HT products is substantially different than marketing products in other categories (e.g., Moriarity and Kosnick, 1989). One of the hallmark characteristics that differentiates products in HT categories from other categories, including FMCG, is uncertainty. We posit that the greater level of uncertainty results in both earlier and later adopters favoring established brand names on more innovative HT products. In an experimental setting, Study 1 found that, contrary to Klink and Athaide (2010), the effect of consumer innovativeness on new product evaluation is not greater for new (vs. existing) brand names on more innovative HT products. Furthermore, we found that highly innovative consumers evaluated more innovative HT products more favorably if such products carried an existing (vs. new) brand name. In a field setting, Study 2 used netnography to corroborate these findings. Specifically, while highly innovative individuals were found to evaluate an incremental HT innovation more favorably with a newer (vs. established) brand, they evaluated more radical HT innovations more favorably with an established (vs. newer) brand. 
An obvious contribution of our work is to help the practicing manager choose an effective branding strategy for HT innovations. Perhaps more importantly, our research helps draw attention to a much needed area of research - i.e., branding and HT products. To illustrate, while brand extensions have been a guiding strategy of businesses over the past few decades, a preponderance of those studies examine packaged goods. Nevertheless, while packaged goods may be the "industry that 'wrote the book' on building strong brands," branding may be more important to HT products than for packaged goods (Mohr, Sengupta, and Slater, 2010, p. 408). Indeed, the results of our studies indicate that using a strong brand is more critical for HT products than for FMCGs, as an established brand is better able to garner acceptance of a more innovative new product.

An important implication of our work is that strong brands may be worth more than previously thought. Given that prior research suggests that earlier adopters favor new brands on new products, our results suggest that established brands may be necessary to help earlier adopters adopt more radical innovations. The added value that an established brand can bestow on radical innovations should be accounted for in valuation models of brand equity.

We add to extant theory on branding strategy and diffusion to include key elements of Dowling and Staelin's (1994) framework of perceived risk - namely, product categoryspecific risk, product-specific risk and consumers' level of acceptable risk. As mentioned in the introduction, well-known theories on branding and diffusion offer opposing prescriptions when it comes to naming a new product. The literature on diffusion and consumer innovativeness purports naming new products with new brands to better appeal to the venturesomeness of innovators. On the other hand, a basic tenet of branding theory is that 
known brands help facilitate acceptance of new products by reducing perceived risk. By accounting for category-specific risk, product-specific risk and acceptable risk, we offer a more nuanced understanding of how innovators will respond to a given innovation.

\section{Limitations and Directions for Future Research}

Our results should be interpreted in light of the limitations of our studies. Perhaps the most notable limitation is that the level of consumer innovativeness of participants in both studies may be skewed higher than the population to adopt. With respect to Study 1 , online respondents tend to be more technologically savvy than participants in other research settings - e.g., mall intercepts. Concerning Study 2, even the participants that were designated as "less innovative individuals" are still conducting a level of innovativeness or opinion leadership that would likely not be present with later adopters in the marketplace. We do take comfort in knowing that consumer innovativeness is a continuous variable that varies across members of the social system (marketplace). Indeed, Rogers (2003) considers the designation of adopter categories based on consumer innovativeness as a "convenience" in describing members of a system. Accordingly, our hypotheses are constructed around this conceptualization of consumer innovativeness.

A limitation is that we did not directly measure consumer innovativeness in Study 2. Instead we used a proxy of innovative behavior - namely, opinion leadership manifested in blog posts to technology forums. Future research may wish to assess branding preferences by examining actual purchase or adoption behavior. As a first step in assessing branding preferences for HT products, another limitation is that we examined only two brand naming strategies - i.e., new vs. existing brand names. Future research should investigate additional 
branding strategies that companies employ such as combining an existing name with a new name-e.g., Microsoft Surface.

Beyond consumer innovativeness, future research may wish to identify additional boundary conditions or moderators to the branding strategy-consumer response relationship. For instance, given that consumers rely more heavily on brands to evaluate services (vs. goods) because of intangibility, we might expect that a strong brand is more critical for radical innovations involving HT services, relative to HT products. In addition, within strong brands, might some possess certain associations (e.g., perceived risk or innovativeness) that might make the brand more or less appealing to certain adopter groups? Finally, given the increasing presence of social media, we encourage future research on branding strategy to take advantage of this research domain in general - and more specifically by replicating Study 2 with additional brands, products, and product categories. 


\section{REFERENCES}

Aaker, D. A., \& Keller, K. L. (1990). Consumer evaluations of brand extensions. Journal of Marketing, 54(January), 27-41.

Aiken, L. S., \& West, S. G. (1991). Multiple regression: Testing and interpreting interactions. Newbury Park, London: Sage.

Ajzen, I., \& Fishbein, M. (1980). Understanding attitudes and predicting social behavior. Englewood Cliffs, N.J.: Prentice Hall.

Alba, J. W., \& Hutchinson, J. W. (1987). Dimensions of consumer expertise. Journal of Consumer Research, 13(March), 411-454.

Ambler, T. \& Styles, C. (1997). Brand development versus new product development: Toward a process model of extension decisions. Journal of Product and Brand Management, 6(4), 222-234.

Bauer, R. A. (1960). Consumer behavior as risk taking, In Dynamic Marketing for a Changing World. ed. R. S. Hancock, Chicago: American Marketing Association, 389-398.

Bettman, J. R. (1979). An information processing theory of consumer choice. Reading, MA: AddisonWesley.

Brooker, G. (1984). An assessment of an expanded measure of perceived risk. In Advances of Consumer Research. Ed. T. C. Kinnear, Provo, UT: Assocation of Consuemr Researrch, 439441.

Castaño, R., Sujan, M., Kacker, M., \& Sujan, H. (2008). Managing consumer uncertainty in the adoption of new products: temporal distance and mental simulation. Journal of Marketing Research, 45(3), 320-336.

Chandy, N. K., Prabhu, J. C., \& Antia, K. D. (2003). What will the future bring? Dominance, technology expectations, and radical product innovation. Journal of Marketing, 67(3), 1-19.

Chandy, R., \& Tellis, G. J. (2000). The incumbent's curse? Incumbency, size and radical product innovation. Journal of Marketing, 64(3), 1-17.

Cooper, R. G. (1994). New products: the factors that drive success. International Marketing Review, 11(1), 60-76.

Dall'Olmo Riley, Francesca, P., Jose M. and Bravo, R. (2013). Downscale extensions: Consumer evaluation and feedback effects. Journal of Business Research, 66, 196-206.

DelVecchio, D and Smith, D. (2005). Brand-extension price premiums: The effects of perceived fit and extension product category risk. Journal of the Academy of Marketing Science, 33(2),184-196.

Dowling, G. R., \& Staelin, R. (1994). A model of perceived risk and intended risk-handling activity. Journal of Consumer Research, 21(June), 119-134.

Erdem, T., \& Swait, J. (1998). Brand equity as a signaling phenomenon. Fang, E. (2008). Customer participation and the trade-off between new product innovativeness and speed to market. Journal of Marketing, 72(4), 90-104.

Fitzsimmons, G. (2008). Editorial: A death to dichotomizing. Journal of Consumer Research, 35(1), 5-8.

Gatignon, H and Robertson, T. (1985). A propositional inventory for new diffusion research. Journal of Consumer Research, 11, 849-867.

Goldsmith, R. E., d'Hauteville, F., \& Flynn, L. R. (1998). Theory and measurement of consumer innovativeness: A transnational evaluation. European Journal of Marketing, 32(3), 340-353.

Goldsmith, R. E., \& Hofacker, C. F. (1991). Measuring consumer innovativeness. Journal of the Academy of Marketing Science, 19(3), 209-221.

Gourville, J. T. (2006). Eager sellers and stony buyers: Understanding the psychology of new-product adoption. Harvard Business Review, June, 99-106.

Govindarajan, V., \& Kopalle, P. K. (2006). Disruptiveness of innovations: Measurement and an assessment of reliability and validity. Strategic Management Journal, 27(2), 189-199.

Gurham-Canli, Z., \& Batra, R. (2007). When corporate image effects product evaluations; the moderating role of perceived risk. Journal of Marketing Research, 41(2), 197-205. 
Han, J. K., Kim, N., \& Srivastava, R. K. (1998). Market orientation and organizational performance: Is innovation a missing link? Journal of Marketing, 62(4), 30-45.

Helmig, B., Huber, J-A, \& Leeflang, P. (2007) Explaining behavioural intentions toward co-branded products, Journal of Marketing Management, 23(3-4), 285-304.

Herbig, P., \& Milewicz, J. (1997). The relationship between reputation and the credibility of brand success. Pricing Strategy \& Practice, 5(1), 25-29.

Hirschman, E. C. (1980). Innovativeness, novelty seeking and consumer creativity. Journal of Consumer Research, 7(December), 283-295.

Hirunyawipada, T., \& Paswan, A. K. (2006). Consumer innovativeness and perceived risk: implications for high technology product adoption. Journal of Consumer Marketing, 23(4), 182-198.

Hoeffler, S. (2003). Measuring preferences for really new products. Journal of Marketing Research, 40, 406-421.

Hoyer, W. D., \& Brown, S. P. (1990). Effects of brand awareness on choice for a common, repeatpurchase product. Journal of Consumer Research, 17(2), 141-148.

Im, S., Mason, C.H. and Houston, M.B. (2007). Does consumer innovativeness relate to new product/service adoption behavior? The intervening role of social learning via vicarious innovativeness. Journal of the Academy of Marketing Science, 35, 63-75.

Irwin, J. R., \& McClelland, G. H. (2001). Misleading heuristics and moderated multiple regression models. Journal of Marketing Research, 38(1), 100-109.

Jacoby, J. \& Kaplan, L. B. (1972). The components of perceived risk. In Proceedings of the $3^{\text {rd }}$ Annual Assocation for COnsumer Research. ed. M. Venkatesan. College Park, MD: Association of Consumer Research, 382-398.

Jacoby, J., Olson, J. C., \& Haddock, R. A. (1973). Price, brand name and product composition characteristics as determinants of perceived quality. Journal of Applied Psychology, 55(6), 570-579.

Janis, I. \& Mann, L. (1977). Decision making: A psychological analyiss of vonflict. Choice and commitment. New York: Free Press.

Kapferer, J.-N. (2008). The New Strategic Brand Management (4th ed.). London: Kogan Page Ltd.

Keller, K. L. (1993). Conceptualizing, measuring, and managing customer-based brand equity. Journal of Marketing, 57(January), 1-22.

Keller, K. L. (2007). Strategic brand management : building, measuring, and managing brand equity (2nd ed.). Upper Saddle River, N.J.: Prentice Hall.

Keller, K. L., \& Lehmann, D. R. (2003). How do brands create value. Marketing Management, May/June, 26-31.

Keller, K. L., \& Lehmann, D. R. (2006). Brands and branding: Research findings and future priorities. Marketing Science, 25(6), 740-759.

Klink, R. R., \& Athaide, G. A. (2010). Consumer innovativeness and the use of new versus extended brand names for new products. Journal of Product Innovation Management, 27(23), 23-32.

Kotler, P., \& Armstrong, G. (2016). Principles of Marketing. 16 ${ }^{\text {th }}$ Ed., Pearson: Boston.

Les Échos (December 7). Étendre sa marque, un pari souvent gagnat, 19301. (p. 15)

(http:// archives.lesechos.fr/archives/2004/LesEchos/19301-50-ECH.htm (in French) (accessed 09 May 2011)).

Loken, B \& Roeder John, D. (1993). Diluting brand beliefs: When do brand extensions have a negative impact? Journal of Marketing, 57(July), 71-84.

Lounsbury, M., \& Glynn, M. A. (2001). Cultural entrepreneurship: Stories, legitimacy, and the acquisition of resources. Strategic Management Journal, 22(6-7), 545-564.

McWilliam, G. (1997). Low involvement brands: is the brand manager to blame? Marketing Intelligence \& Planning 15(2), 66-70.

Mahajan, V., \& Muller, E. (1998). When is it worthwhile targeting the majority instead of the innovators in a new product launch? Journal of Marketing Research, 25(November), 488-495.

Manning, K.C., Beardon, W.O. and Madden, T.J. (1995). Consumer innovativeness and the adoption process. Journal of Consumer Psychology, 4(4), 329-345. 
Maslow, A. (1954). Motivation and personality. New York: Harper.

Mick, D.G. and Fournier, S. (1998). Paradoxes of technology: Consumer cognizance, emotions, and coping strategies. Journal of Consumer Research, 25, 123-143.

Midgley, D. F., \& Dowling, G. R. (1978). Innovativeness: the concept and its measurement. Journal of Consumer Research, 4(4), 229-242.

Midgley, D. F., \& Dowling, G. R. (1993). A longitudinal study of product form innovation: The interaction between predispositions and social messages. Journal of Consumer Research, 19(4), 611-625.

Mohr, J. J., Sengupta, S., \& Slater, S. (2010). Marketing of High-Technology Products and Innovations (3rd Edition). New York: Prentice Hall.

Moore, G. (2004). Crossing the chasm. $3^{\text {rd }}$ Edition. New York: Harper Collins.

Moriarty, R. \& Kosnik, T. (1989). High Tech Marketing: Concepts, Continuity, and Change, Sloan Management Review, 30(4), 7-17.

Ogiba, E. (1988). The Dangers of Leveraging. Adweek (January 4), 42.

Roerich, G. (2004). Consumer innovativeness - Concepts and measurements. Journal of Business Research, 57(6), 671-677.

Roerich, G., Valette-Florence, P and Ferrandi, J-M. (2002). An exploration of the relationship between innate innovativeness and domain specific innovativeness. Asia Pacific Advance in Consumer Research, 5, 379-386.

Rogers, E. M. (2003). Diffusion of innovations (4th ed.). New York: The Free Press.

Rogers, E. M., \& Shoemaker, F. F. (1971). Communication of innovations. New York: The Free Press.

Roselius, T. (1971). Consumer ranking of risk reduction methods. Journal of Marketing, 35(1), 56-61.

Silayoi, P. \& Speece, M. (2004). Packaging and purchase decisions: An exploratory study on the impact of involvement level and time pressure, British Food Journal, 106(8), $607-628$.

Smith, D. C., \& Park, C. W. (1992). The effects of brand extensions on market share and advertising efficiency. Journal of Marketing Research, 29(August), 296-313.

Somji, Amin (2000). Inside New Product Statistics. unpublished MA in Marketing thesis, Kingston Business School.

Spiller, S. A., Fitszimons, G. J., Lynch, Jr., J. G. and McClelland (2013). Spotlights, floodlighs, and the magic number zero: Simple effects tests in moderated regression. Journal of Marketing Research, L(April), 277-288.

Stigler, G. (1961). The economics of information. Journal of Political Economy, 69(3), 213-225.

Taylor, J. (1974). The role of risk in consumer behavior. Journal of Marketing, 39(April), 54-60.

Temporal, P., \& Lee, K. C. (2000). Hi-tech and hi-touch branding: Creating brand power in the age of technology. New Delhi: Wiley Eastern.

Tripat, G., \& Lei, J. (2009). Convergence in the high-technology consumer markets: Not all brands gain equally from adding new functionalities to products. Marketing Letters, 20, 91-103.

Wernerfelt, B., \& Umbrella branding as a signal of new product quality: An example of signaling by posting a bond. Rand Journal of Economics, 19(Autumn), 458-456.

Winkler, A. M. (1999). Warp-speed branding: The impact of technology on marketing. NewYork, NY: John Wiley \& Sons.

Wu, Y., Balasubramanian, S., \& Mahajan, V. (2004). When is a preannounced new product likely to be delayed? Journal of Marketing, 68(2), 101-113.

Zajas, J., \& Crowley, E. (1995). Commentary: brand emergence in the marketing of computers and high technology products. Journal of Product \& Brand Management, 4(1), 56-63. 
TABLE 1: Study 1 -- Multiple regression analyses

\begin{tabular}{|c|c|c|c|c|}
\hline $\begin{array}{l}\text { Independent } \\
\text { Variables }\end{array}$ & $\begin{array}{l}\text { Model } 1 \\
(n=520)\end{array}$ & $\begin{array}{l}\text { Model } 2 \\
(n=520)\end{array}$ & $\begin{array}{l}\text { Model } 3 \\
\text { Radical products } \\
\text { only } \\
(n=260)\end{array}$ & $\begin{array}{l}\text { Model } 4 \\
(n=520)\end{array}$ \\
\hline $\begin{array}{l}\text { Consumer } \\
\text { Innovativeness }\end{array}$ & $.533^{* * *}$ & $.535^{* * *}$ & $.489 * * *$ & $.523 * * *$ \\
\hline Brand Name & & $.099 *$ & $.181 * *$ & $.096 *$ \\
\hline Innovation Type & & & & $.184^{* * *}$ \\
\hline $\begin{array}{l}\text { Consumer } \\
\text { Innovativeness } \mathrm{x} \\
\text { Brand Name }\end{array}$ & & $-.053 *$ & .015 & $-.062^{*}$ \\
\hline $\begin{array}{l}\text { Consumer } \\
\text { Innovativeness x } \\
\text { Innovation Type }\end{array}$ & & & & -.039 \\
\hline $\begin{array}{l}\text { Brand Name } x \\
\text { Innovation Type }\end{array}$ & & & & $.085^{*}$ \\
\hline $\begin{array}{l}\text { Consumer } \\
\text { Innovativeness } x \\
\text { Brand Name x } \\
\text { Innovation Type }\end{array}$ & & & & $.078^{* *}$ \\
\hline Constant & $3.083 * * *$ & $3.092 * * *$ & $3.472 * * *$ & $3.137^{* * *}$ \\
\hline Adjusted $R^{2}$ & .42 & .43 & .44 & .46 \\
\hline F-score & $385.00 * * *$ & $133.20 * * *$ & $68.81 * * *$ & $65.31 * * *$ \\
\hline
\end{tabular}

Dependent Variable $=$ New Product Evaluation

$* \mathrm{P}<.05$

$* * p<.01$

$* * * p<.001$ 
FIGURE 1: Study 1 - Effect of brand name strategy on new product evaluation for incremental and radical innovations

Figure 1a

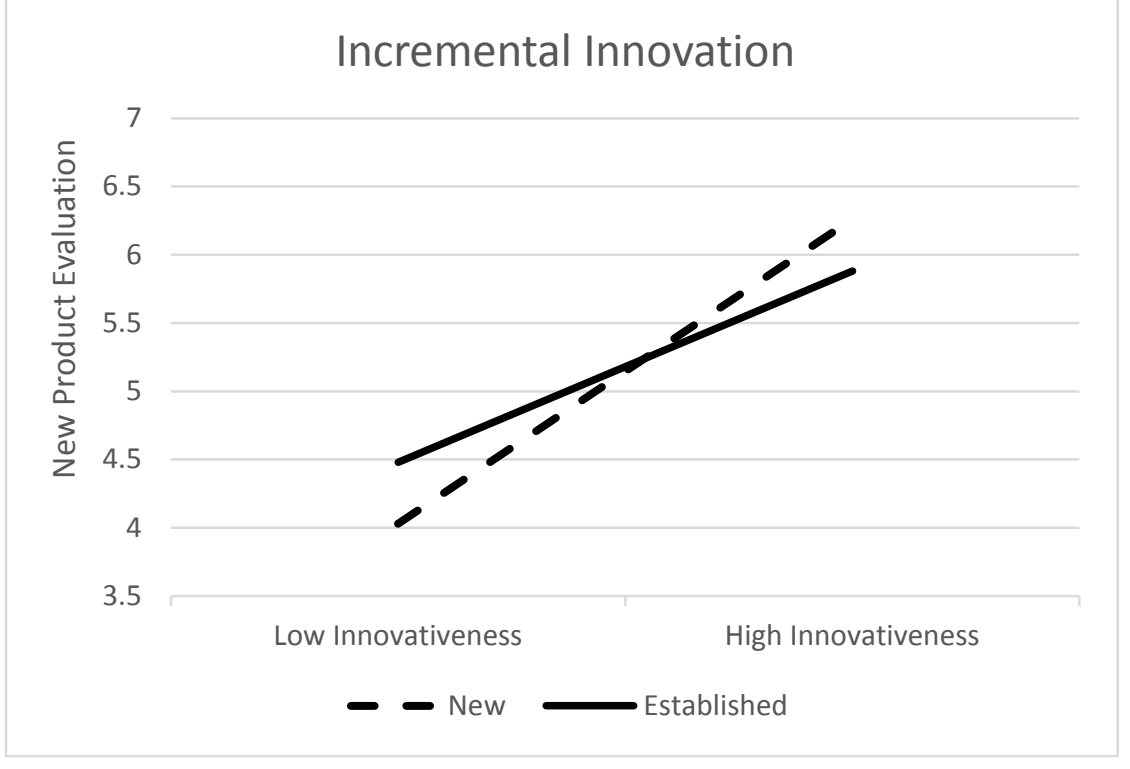

Figure $1 b$

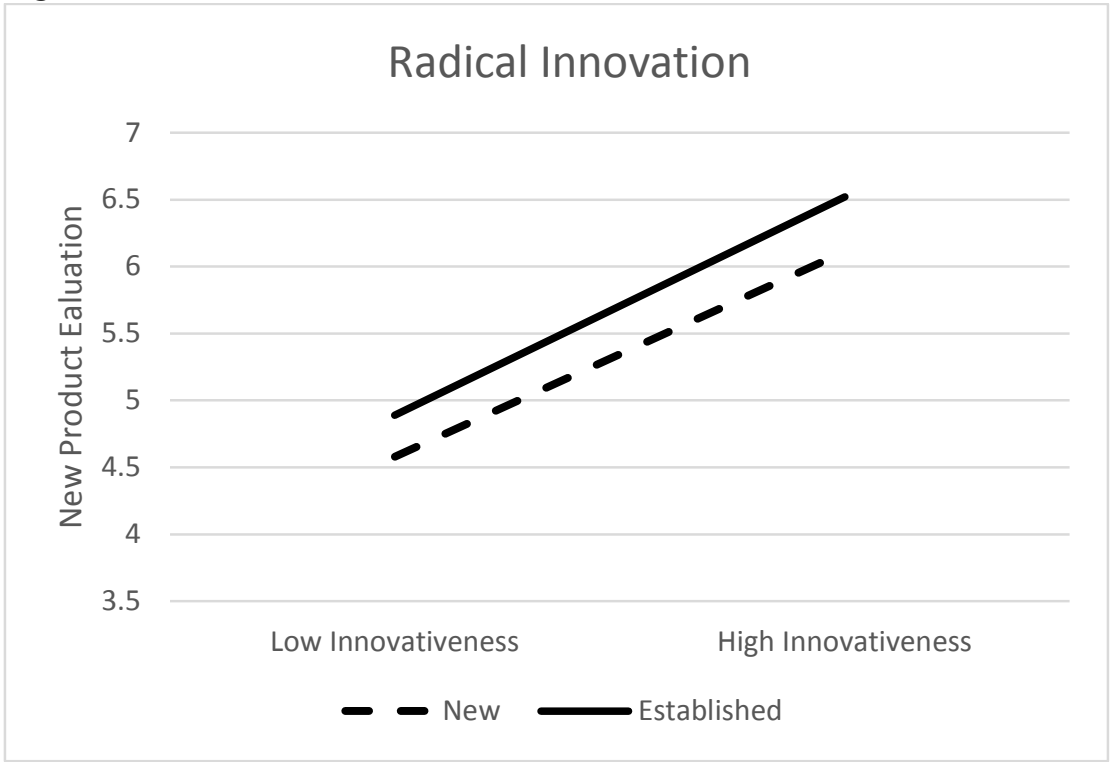


APPENDIX 1: Study 1 - Product illustration

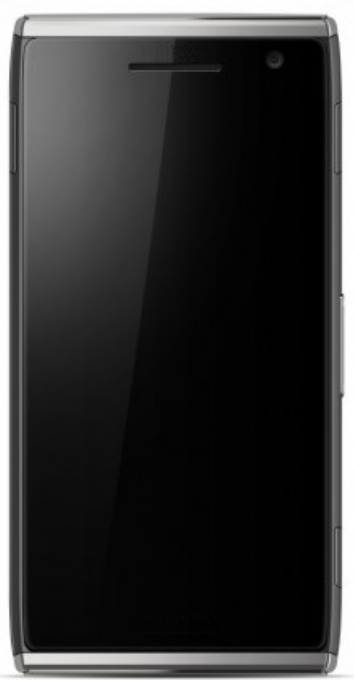

